\section{Use of an Alternate Light Source to Detect Tooth and Bone}

\author{
Geraldo Elias Miranda1,2,3, Rodolfo Francisco Haltenhoff Melani3 ${ }^{3}$, Luiz \\ Francisquini Júnior ${ }^{1}$, Eduardo Daruge Júnior ${ }^{1}$
}

\author{
'Department of Social Dentistry, \\ Piracicaba Dental School, UNICAMP \\ - Universidade Estadual de \\ Campinas, Piracicaba, SP, Brazil \\ ${ }^{2}$ Institute of Legal Medicine, \\ Polícia Civil de Minas Gerais, \\ Belo Horizonte, MG, Brazil \\ ${ }^{3}$ Department of Social Dentistry - \\ Laboratory of Forensic Anthropology \\ and Odontology (OFLAB), Dental \\ School, USP - Universidade de \\ São Paulo, São Paulo, SP, Brazil
}

Correspondence: Geraldo Elias Miranda, Rua Nícias Continentino, 1291, 30510-160 Belo Horizonte, MG, Brasil. Tel: +55-31-3785-1369. e-mail: geraldoelias@usp.br

Key Words: fluorescence, tooth, bone, alternate light source, crime scene investigation.

\section{Introduction}

The alternate light source (ALS) is a simple method that can be used to locate biological evidence in crime scenes $(1,2)$. ALS is effective, non-invasive, non-destructive, and may detect biological fluids (3), human remains (4), teeth and bones (5) and other types of evidence. For a positive identification of a victim, in many cases it is essential to accurately locate and recover fragments of bones and teeth. Therefore, the use of an ALS may be helpful when searching for human bones, teeth and other remains (5).

The ALS technology is based on the absorptive and fluorescent properties of the item under examination (6). Fluorescent materials absorb light at low wavelengths and emit light at higher wavelengths than the absorbed ones (2). Not all substances show fluorescence, and besides, each fluorescent material requires excitation by a specific range of wavelengths. Light with a wavelength outside this range does not contribute to the excitation of the sample. Therefore, to detect a specific material, it is important to know the best combination of wavelength and filter.

Contributing to the development of technologies for biological detection, the results of this study may assist forensic experts in identifying evidence both at crime scenes and in the lab. This is important, because incomplete analyses may result in the loss of crucial evidence such as teeth and small bones. In some cases, bone and dental tissue may not always be easily identifiable from non-osseous material $(7)$. Moreover, some authors $(2,4)$ have suggested that new research should be performed to perfect the ALS technique. Other papers $(8,9)$ studied the bone fluorescence but they did not compare the tooth fluorescence with bone as done in this study.

The objective of this study was to identify the combination of wavelength and filter that best detects tooth and bone, and to verify which biological material (enamel, dental root and bone) has greater fluorescence when exposed to ALS.

\section{Material and Methods}

The Research Ethics Committee of the Piracicaba Dental School (FOP/UNICAMP) approved the study under case no. 051/2012.

The experiments used samples of tooth and bone (biological material) mixed with Styrofoam balls (inert material). The sample consisted of three extracted human molars and three fragments of dried human bones $(n=3)$, measuring approximately $20 \times 20 \times 10 \mathrm{~mm}$ each. The cement tissue remained on the samples, so the dental root fluorescence refers to dentin and cement as described in a previous paper (10). Styrofoam was used as a nonbiological material (inert material) to contrast with the skeletal tissues (biological material), since both are light colored when viewed with the naked eye to simulate a distracting background.

The samples were exposed to a Megamax ${ }^{\mathrm{TM}}$ Alternative Light Source (ALS) System (Sirchie, Youngsville, NC, USA) which comprises light sources generating individual wavelengths of $455,470,505,530,590$ and $625 \mathrm{~nm}$. The ALS equipment was set on a tripod, to maintain a fixed 
distance between the ALS and the analyzed sample and to normalize the illumination in all tests. A diffusor attached to a lamp was used to make the light softer and evenly distributed (11).

Photographs were obtained with a Canon EOS 60D digital camera, using a Canon EF-S $60 \mathrm{~mm}$ f/2.8 Macro USM lens (Canon Inc., Tokyo, Japan) and yellow 8 , orange 21 or red 25 filters (Tiffen Company, NY, USA). The camera rested on a tripod to avoid movement. The camera was controlled by a computer with the Canon EOS Utility ${ }^{\mathrm{TM}}$ software (Canon Inc.). The camera's ultraviolet (UV) filter was removed, to guarantee that the camera's sensor would pick up light near the UV range, as practiced by Lee (12). Photographs were made in a completely darkened room.

Photoshop ${ }^{\mathrm{TM}}$ (Adobe Systems, San Jose, CA, USA) was utilized to prepare the photographs for analysis and the Image $\mathrm{J}^{\mathrm{TM}}$ (National Institutes of Health, Bethesda, MD, USA) was employed to record the brightness values of pixels in the images. First, Photoshop ${ }^{\mathrm{TM}}$ was used to select regions of interest (ROIs), measuring 100×100 pixels, from images of enamel, root and bones (Figs. 1 and 2). ROls are areas in the same size, selected and cut with Photoshop in the same positions in all the samples to maintain a standard in the analysis of the measurements. These ROIs were transformed into 8-bit/channel "grayscale" images, so that the color information could be discarded, to maintain consistency during the analyses (13). The obtained images were saved in TIFF format.

Next, Image $J^{T M}$ software was used to obtain the average brightness value within the ROI. Each pixel was assigned a numerical value that represented its brightness on the grayscale (8), ranging from 0 (completely black pixel) to 255 (completely white pixel) (8).

Data were subjected to analysis of variance (ANOVA), using a generalized linear mixed model with three fixed effects. The assumption that the error had a Gaussian distribution was analyzed through the asymmetry and kurtosis coefficients and the Shapiro-Wilk test. The mean

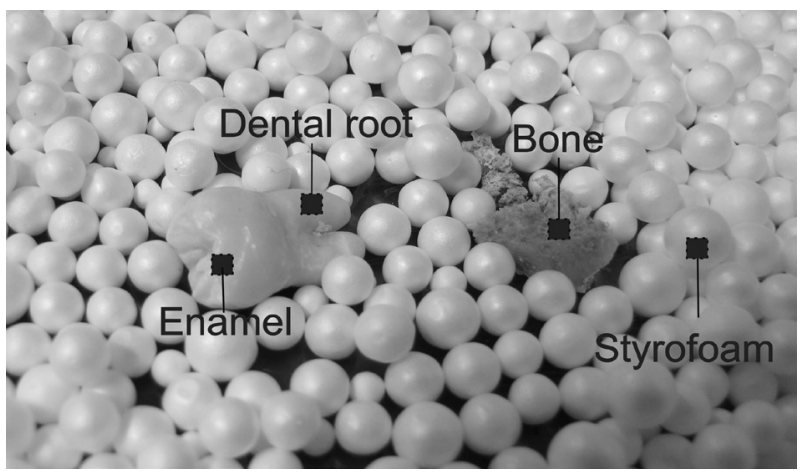

Figure 1. ROIs exposed to natural light. values of significant effects were compared by the Tukey test. In all tests, the significance level was $p \leq 0.05$. Statistical values were calculated by the SAS system (SAS Institute Inc., Cary, NC, USA).

\section{Results}

ANOVA was applied to compare the mean brightness of materials, filters, wavelengths and their interactions up to third order values. ANOVA results for factors that influenced the brightness, with an appropriate model for randomized experiments with factorial $(6 \times 3 \times 4)$ found significant differences $(p<0.01)$ in the average of all tested effects. Subsequently, the Tukey-Kramer test for comparison of means was chosen to determine the most relevant results within these comparisons, as presented in Figure 3.

Figure 3 demonstrates the results of the Tukey-Kramer test for comparison of mean brightness due to the interaction of the triple wavelength of $455 \mathrm{~nm}$ and the orange filter. Under these circumstances, the fluorescence of the dental root was the greatest followed by the enamel and then the bone. Means labeled with the same letter in Figure 3 do not differ at a 5\% significance level.

The difference between the brightness of biological and inert material was calculated to check the visibility of the bone, root and enamel. The same ANOVA model was used; however, in this case the inert material was not examined because it was the reference brightness, which results in a factor $(6 \times 3 \times 3)$. The results found significant differences $(p<0.01)$ in the average of all tested effects. Tukey's test was applied for comparing the mean difference in the brightness of different materials in relation to inert material, using $455 \mathrm{~nm}$ light and an orange filter. The dental root presented a mean brightness of 169.33 with standard deviation of 0.58 ; enamel 114.33 with standard deviation of 1.15 and bone 85.00 with standard deviation of 1.00 .

Table 1 presents photographs of the biological and inert material by varying the incident light wavelength and emission filter.

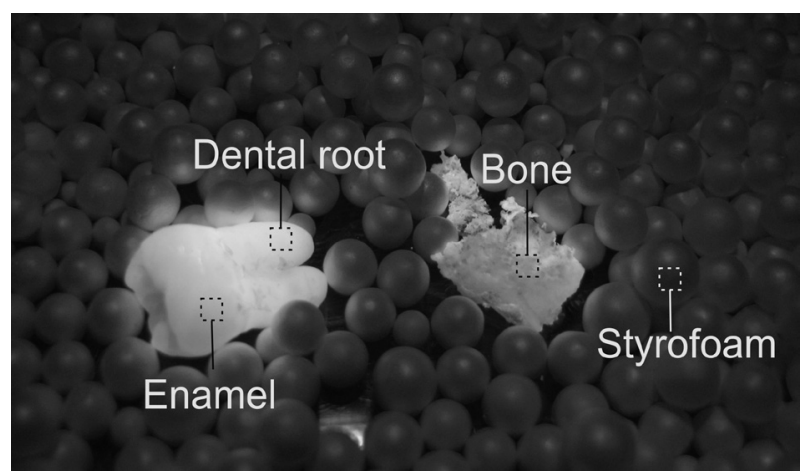

Figure 2. ROIs exposed to the ALS. 


\section{Discussion}

The best combination to detect bone and tooth with ALS is a $455 \mathrm{~nm}$ illumination with an orange filter. Under these conditions, the biological material had markedly higher fluorescence than the inert material. A similar result was reported in a previous study (5), but the authors of that study did not evaluate the difference in brightness between the biological material and the background. Sterzik et al. (9) found out that the strongest fluorescence reaction for bone was caused by $490 \mathrm{~nm}$ wavwlength in combination with a dark red filter. However, those authors worked only with bone and researched the fluorescence to estimate the postmortem interval. Swaraldahab (8) used the same wavelength $(490 \mathrm{~nm})$ but with an orange filter.

The difference in brightness is important because it represents how the biological material will appear against the background at a crime scene, and thus how easy it may be for the forensic expert to detect it visually. Because the present study has identified that the orange filter and a $455 \mathrm{~nm}$ light produce the greatest difference in brightness between skeletal tissues and the analyzed inert material, this combination should be added to the toolbox of the forensic experts for finding such biological evidence at a $\vec{s}$ crime scene or in the laboratory.

In a previous study, the samples of tooth and bone were mixed with various kinds of stone (5). However, the authors of the previous study did not make a statistical analysis, as was done in this study. Backgrounds vary considerably in forensic contexts. In this study, Styrofoam balls were used as negative control, but there are plenty of other materials that could be used to compare the biological sample with non-biological materials commonly found in a crime scene. Swaraldahab (8) used a non-fluorescent sheet of white paper as negative control. That was one of the limitations of this study, since only one background material was tested. More research is required to test other

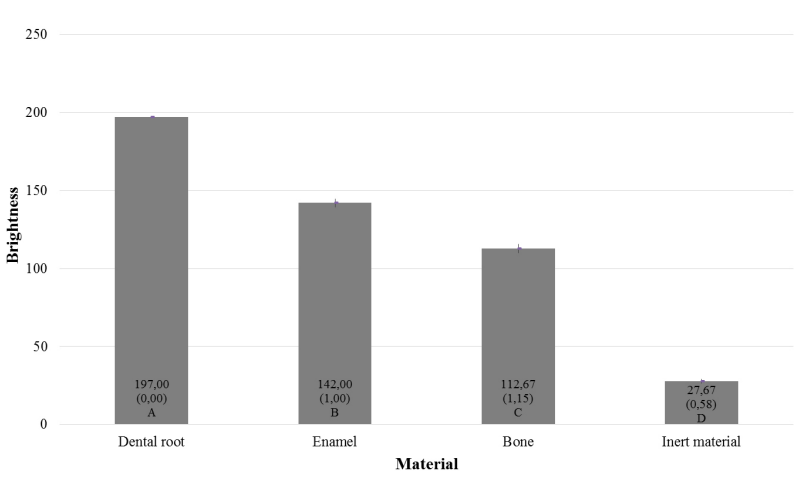

Figure 3. Mean (standard deviation), limits of the confidence interval (95\%) and Tukey's test for comparison of mean brightness of different materials used when using the wavelength of $455 \mathrm{~nm}$ and an orange filter. backgrounds.

After the best combination of illumination and filter was identified, the different types of biological material (bone, dental root and enamel) were analyzed to determine which had the highest fluorescence. The results showed that the fluorescence of dental root is greater than that of enamel, which in turn is higher than that of bone. Even small fragments of bone and enamel emit significant fluorescence, which are best viewed in a dark environment (5). ALS can be used to effectively detect bones in underwater environments, as well as field or laboratory settings, especially in conditions involving little or no daytime light. In field or laboratory settings when bones or bone fragments are mixed with other materials or debris, this technique may be used to quickly locate and separate the bones from the other materials (14). These fragments may not be visible initially to the naked eye, mainly when mixed into a distracting or dark background (8). Even the smallest bony fragment, which may appear unimportant to the eyes of an inexperienced observer, can provide essential information (15). These small fragments of evidence may be useful for identifying the victim or to help solve a crime.

Studies have shown that dentin is strongly fluorescent due to its higher amount of organic material (16). Enamel is also fluorescent, albeit to a lesser degree (16). However,

Table 1. Photographs of biological (tooth and bone samples) and inert (styrofoam balls) materials under different combinations of illumination wavelength (nm) and filter

\begin{tabular}{|c|c|c|c|}
\hline \multirow{2}{*}{$\mathrm{nm}$} & \multicolumn{3}{|c|}{ Filter } \\
\hline & Yellow & Orange & Red \\
\hline 455 & & & \\
\hline 470 & & & \\
\hline 505 & & & \\
\hline 530 & & & \\
\hline 590 & & & \\
\hline 625 & & & \\
\hline
\end{tabular}


these prior studies did not analyze the fluorescence of bone. The differences in fluorescent properties are possibly related to the organic component of bone because neither the burned bone nor the dental enamel fluoresced under these conditions (bones that have been burned lose their organic component and enamel has little organic component) (14). Bone fluorescence decreases with time, but some fluorescence is retained even in older samples (8).

ALS can also be used in dentistry to locate resin restorations, since light can reveal the contrast between the tooth and resin $(10,17)$. The speed with which ALS can be deployed makes this technique well suited to be an adjunct method in forensic dental examinations (17). Inspection with light by ALS is rapid and can reveal evidence that would otherwise be difficult to observe $(7,11,17)$; its use can provide additional information that contributes to identify positively the crime victims.

This knowledge can help the forensic expert to screen and detect biological materials, for example in situations where teeth and small bones are fragmented, both at the scene and in the laboratory. This study demonstrated that an ALS with a $455 \mathrm{~nm}$ wavelength and an orange filter can not only detect but also differentiate bone and tooth fragments mixed with other debris.

\section{Resumo}

0 objetivo desse trabalho foi identificar a combinação do comprimento de onda e filtro que melhor detecta dente e osso e verificar qual material biológico (esmalte, raiz dental ou osso) possui maior fluorescência quando exposto a uma fonte de luz alternativa (ALS). Amostras de dente e osso foram iluminadas com uma ALS e fotografadas. Os programas Adobe Photoshop ${ }^{T M}$ e Image ${ }^{T M}$ foram usados para análise das imagens. Os dados obtidos das medidas dos pixels das fotografias foram submetidos a análise de variância. Os valores com efeitos significativos tiveram suas médias comparadas pelo teste de Tukey. Em todos os testes, o nível de significância adotado foi $p \leq 0,05$ e os valores calculados pelo sistema SAS. Os resultados mostraram que a melhor combinação para detectar dente e osso é o comprimento de onda $455 \mathrm{~nm}$ com o filtro laranja. A fluorescência da raiz é maior que a do esmalte que é maior do que o osso. 0 material biológico teve maior fluorescência que o material inerte. Esse conhecimento pode auxiliar o perito a triar e detectar esses materiais biológicos, por exemplo em situações em que dentes e pequenos ossos estiverem fragmentados, tanto na cena do crime quanto no laboratório.

\section{References}

1. Virkler K, Lednev IK. Analysis of body fluids for forensic purposes: from laboratory testing to non-destructive rapid confirmatory identification at a crime scene. Forensic Sci Int 2009;188:1-17.

2. Lee WC, Koo BE. Forensic light sources for detection of biological evidences in crime scene investigation: a review. MJOFS 2010;1:17-27.

3. Vandenberg N, Oorschot RAH. The use of Polilight in the detection of seminal fluid, saliva, and bloodstains and comparison with conventional chemical-based screening tests. J Forensic Sci 2006;51:361-370.

4. Gallant AS. Alternate light sources in the detection of bone after an accelerated fire: a pilot study. J Forens Sci 2013;58:221-226.

5. Craig EA, Vezaro N._Use of an alternate light source to locate bone and tooth fragments. J Forensic Identi 1998;48:451-457.

6. Viner TC, Kagan RA, Johnson JL. Using an alternate light source to detect electrically singed feathers and hair in a forensic setting.
Forensic Sci Int 2014:234:25-29.

7. Zimmerman HA, Schultz JJ, Sigman ME. Preliminary validation of handheld $\mathrm{x}$-ray fluorescence spectrometry: distinguishing osseous and dental tissue from non-bone material of similar chemical composition. J Forensic Sci 2015;60:282-390.

8. Swaraldahab MAH, Christensen AM. The effect of time on bone fluorescence: implications for using alternate light sources to search for skeletal remains. J Forensic Sci 2016;61:442-444.

9. Sterzik V, Jung $T$, Jellinghaus $K_{1}$ Bohnert M. Estimating the postmortem interval of human skeletal remains by analyzing their optical behavior. Int J Legal Med 2016. DOI 10.1007/s00414-016-1395-3

10. Carson DO, Orihara Y, Sorbie JL, Pounder DJ. Detection of white restorative dental materials using an alternative light source. Forensic Sci Int 1997;88:163-168.

11. Miranda GE, Prado FB, Delwing F, Daruge Junior E. Analysis of the fluorescence of body fluids on different surfaces and times. Sci Justice 2014;54:427-431.

12. Lee WC, Khoo BE, Abdullah AFLB, Abdul Aziz ZB. Statistical evaluation of alternative light sources for bloodstain photography. J Forensic Sci 2013;58:658-663.

13. Farrar A, Porter G, Renshaw A. Detection of latent bloodstains beneath painted surfaces using reflected infrared photography. J Forensic Sci 2012;57:1190-1198.

14. Christensen AM, Horn KJ, Smith VA. The use of an alternate light source for detecting bones underwater. J Forensic Sci 2014;59:1046-1048.

15. Porta D, Poppa P, Regazzola V, Gibelli D, Schillaci DR, Amadasi A, et al.. The importance of an anthropological scene of crime investigation in the case of burnt remains in vehicles: 3 case studies. Am J Forensic Med Pathol 2013;34:195-200.

16. Baratieri LN, Araujo E, Monteiro JS. Color in natural teeth and direct resin composite restrations: essencial aspects. Eur J Esthet Dent 2007;2:172-86.

17. Hermanson AS, Bush MA, Miller RG, Bush PJ. Ultraviolet illumination as an adjunctive aid in dental inspection. J Forensic Sci 2008;53:408-411.

Received March 12, 2016 Accepted October 24, 2016 